\title{
Impact Of Globalization On Women's Health Due To Work In Pakistan
}

\author{
Asma Manzoor \\ \& \\ Saba Imran Ali \\ Women's Studies \\ University of Karachi
}

\begin{abstract}
The process of globalization, financial integration, free trade and investment has profoundly transformed the lives of women through out the world. Globalization policies have been preceded by national adjustment proposals, privatization of state enterprises, restructuring of employment policies from secure employment to flexible, temporary work, relaxation of labour laws, etc. which leads to the opening of markets. The world Bank and IMF have created an unjust packet of neo-liberal policies called Structural Adjustment Policies (SAP) and caused enormous difficulties for poor nations. Furthermore, behind the whole process of globalization unscrupulous employers are abusing the basic rights of a predominant young female workforce. This study has been designed to find out the effects of globalization on women's health and their lives and show the human cost of the globalization experiment in Pakistan.
\end{abstract}

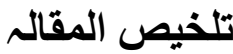

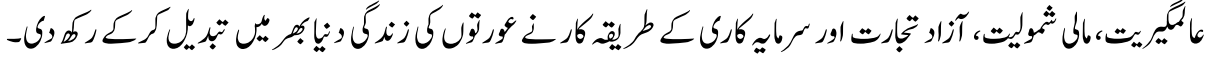

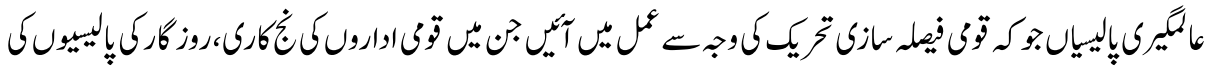

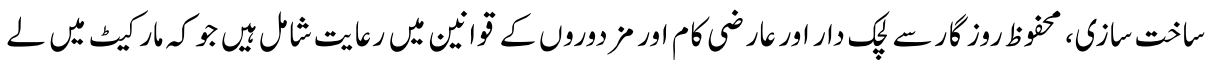

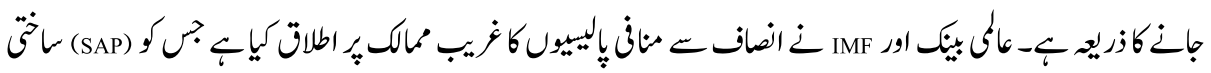

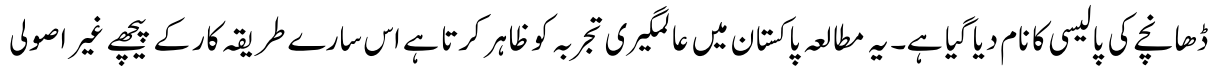

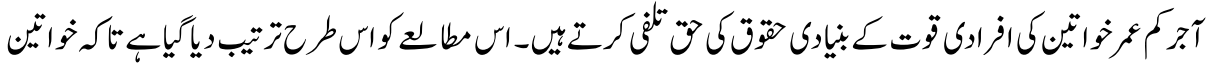

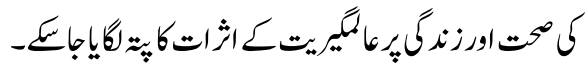

The globalization debate is far too embroiled in unresolved philosophical, conceptual and political issues for anyone to claim to be able to offer a purely factual and incontestable set of definitions. Taken at its most general level, globalization can be defined as the growing interconnectedness and interrelatedness of all aspects of society (Jones, 2006). It 
can be understood as a process, and identified in almost every dimension of contemporary life. While in no sense a novel development in human history, globalization has become considerably more pronounced since the mid-twentieth century.

It is applied to various different dimensions of social life in the contemporary world, spanning cultural, technological, informational, environmental and political transformations - to name but a few of the more significant spheres of globalization's conceptual reach.

During the 1960's, a number of strands of academic theory were engaging with the development-as-modernization' paradigm which had characterized the new Bretton Woods institutions approach to the developing world. Many drew on classical; social, political and philosophical theories including Marx Weber and Durkheim. However, it was not until the late 1980's that globalization as a term began to become common currency between these various discrete literatures and sphere of discussion. The debate comes into emergence in the early 1990's, the world was not so familiar to anyone outside a limited groups. This process accelerated through the 1990's as globalization usage 'took off', first measurably in the number of academic articles then quickly in book titles and newspapers. By the mid-1990's, the word had ceased to be an obscure jargon and could be found across the internet and popular media. Its entrance into all major languages and every day usage probably became assured when mass protests at G8 summits began to be attributed to the 'anti-globalization' movement in the later 1990's (Jones, 2006).

Globalization also involves cultural and moral values and has had particular impact on taste. History has recorded previous waves of globalization, with the most recent one taking place during the colonial era. Similar to today's movement but on a smaller scale and at a slower pace, the Muslim world itself was a major source of one such wave of globalization, which rippled out from the Mediterranean basin several centuries ago, bringing about transfers of goods, people, information and technology.

The impact of the current globalization on the world has been varied, with positive and negative outcomes for different nations, where as Malaysia, for instance, has benefited enormously from one particular aspect of globalization, namely, trade, and the interwoven international financial networks proved disastrous to the Indonesian economy during the 1997- 1998 Asian financial crisis. The globalization of communications technologies, for its part, is exerting tremendous impact across the world, particularly youth (The Center for Dialogues: Islamic World, 2006).

The new globalization environment has driven several developing countries with a sizeable public sector to adopt policy reforms including macroeconomic and financial stabilization policies, creation of market-oriented environment and more space for the 
private sector. This goes hand in hand with increasing internationalization of goods, services, labour and capital, and exchange and exposure of human beings for development oriented programmes. However, such a process is likely to have far reaching effect on health--both direct and indirect particularly in developing countries, where health attainments are low and majority of population lacks resources to finance their healthcare needs. The dynamics, mechanism and pathways through which the process of globalization affects the health sector is not yet clear as their linkages are complex and influenced by several key set of endogenous and exogenous factors (Arora, 2004).

This background of globalization helps us to derive the following key points worth considering in the context of evaluating its impact on the health sector:

(i) Globalization is a reality now and it is being demonstrated as more or less the necessary foundation for productivity, growth and development.

(ii) Globalization process, world governance, and changes in nation-state development policies and allied institutions, all go together.

(iii) The national economic environment has to be changed by making conscious efforts towards market-orientation by launching policy changes at all levels to realign the forces of market versus state in order to create market oriented environment and more space for the private sector over the period. This requires state's quantitative withdrawal from all economic spheres to give more space to the private sector. This will have serious impact on the political economy structure of the country.

(iv) Domestic business have come under strong pressures as the pattern of competitiveness has undergone a serious change with non-price factors like product quality, brand name, packaging, and delivery, and after sales services.

Such a process of globalization, no doubt, has promoted open societies and open economies along with encouraging a relatively freer exchange of goods, ideas and knowledge, and creativity and entrepreneurship in some parts of the world along with contributing towards awareness of rights and identities enabling social movements to strengthen democratic accountability. According to World Development Report 2003, over 200 million people came out of poverty in a single decade in East Asia. Global conscience, at least theoretically speaking, is expressing its concern more than ever before regarding income inequities, poverty, gender discrimination, child labour, health hazards and environmental degradation.

During the course of globalization, general economic risks of the developing countries have become more real. The fundamental problems of poverty, unemployment, exclusion, inequality and corruption are still widespread. This process of globalization is likely to have far reaching impact on the health sector in developing countries, 
particularly the SAARC members. Determinants of health range widely to include income and wealth, education, peace and security, and environmental conditions are likely to be influenced during the globalization process especially in public sector dependent economies (Arora, 2004).

In Asia, globalization has resulted in growing foreign debts of poor countries, financial crises of 1997 in East Asia and South East Asia, growing inequality within and among countries, unemployment, underemployment, and poverty. In addition, globalization in Asia has been responsible for social unrest, drugs, growth of the culture of violence, trafficking of people, and neo-colonization that can be called "homogenization and hegemonization".

In Pakistan, globalization has resulted in racial and religious discrimination, economic barriers, break down in family relationships, and lack of community. Also problems of getting jobs, inflation, currency devaluation and growth of Islamic fundamentalism have become widespread. The inflow of money from the Gulf regions and grants from World Bank have changed the lifestyle of the people. The life of the common people has become difficult. The basic amenities of life have become very expensive and are out of the reach of common people. Due to this change, availability of civic facilities is found in the cities only. Urbanization has become unavoidable for rural people who migrate to the cities for the sake of these facilities and to earn a livelihood. The prices of land and other basic necessities in the cities have growing costlier day by day, going out of the reach of common people. The cost of living in the cities is high and only few from rural areas can dream to study in good education and institutes. As a result, the young people suffer from depression, lack of motivation and determination (Dass, 2002).

Women in Pakistan, like elsewhere in the developing world, face growing insecurity due to increasing competition. Also, there is no guarantee of gaining access to emerging opportunities unless steps are taken to increase their socio-economic empowerment. If Pakistan is to prosper in this globalization era, it needs to ensure that the marginalized women can become more astute and efficient.

It is said that poverty today has a woman's face. Out of 1.3 billion poor in the world, 70 percent are women. Several UN agencies concur that this feminization of poverty persists even though women produce 60 percent of all food, run 70 percent of small-scale businesses worldwide and constitute a third of the global labour force. Besides doing all this, women have a disproportionate burden of managing their families and homes.

Unfortunately globalization is further intensifying pressure on women around the world. The liberalization of agriculture sector, for example, has affected women in a variety of ways, ranging from increased competition for their products in local markets to their dislocation from traditional forms of livelihood. They also find it more difficult due to 
decline in food subsidies, to manage their households. Budget cuts in the public sector expenditure are compelling women to take on greater responsibilities to address the basic needs of their families. This is particularly true of poor families where women's earnings have become critical to subsistence of households. Due to globalization, more women are seeking opportunities to earn a livelihood. The trend is not helping improve the quality of their lives. Lack of education and skills is forcing most of these women to work either in the informal sector or in the secondary sector of an increasingly segmented labour market. Working conditions are harsh and the benefits meager (Ali, 2004).

Due to the unchecked destabilizing effects of globalization, women's work is getting harder and take longer. On one hand, globalization has placed greater pressure on women to ensure survival of the family and on the other, their share in food and nutrition intake is decreasing. This threatens not only their own health, but also that of their children. These trends have particularly grave consequences for Pakistan which already has some of the worst gender development indicators in the South Asian region. Findings of the Human Development in South Asia Report reveal that female economic activity rate in Pakistan is lowest and unemployment rate highest in the region. In the absence of reliable macro-level data, it is difficult to assess the gender-specific impact of globalization. However several studies have highlighted adverse impact of globalization on marginal groups especially poor rural women.

Rural women in our country remain at the lower end of the skill and knowledge base. They shoulder an excessive work burden. They have little social protection and lack access to basic social services like health and education. Most of these women also have very limited or no entitlements in terms of access and control over income and resources. Being underpaid, and largely unorganized, these marginalized women are hardly in a position to negotiate better terms for themselves (Ali, 2004).

Globalization policies have been preceded by national adjustment proposals, privatization of state enterprises, restructuring of employment policies from secure employment to flexible, temporary work heading to opening of new markets. The World Bank and IMF have created an unjust packet of policies called Structural adjustment Policies (SAP) and imposed it as a model on poor nations which badly affects the health of people specially the women. The end result is that the state is coercive arm is becoming stronger while its caring side is being rolled back.

Globalization is riding on the back of millions of poor women and child workers living on the margins of economy. The structural adjustment programme has forced working women into unorganized sector and deprived them of their rights. In response to a mounting burden of debt, leading to a balance of payment crisis, the Government of Pakistan embarked on a Structural Adjustment Programme (SAP) in the 1990s. This included reduction in public investment, devaluation, cutting food and fertilizer subsidies, 
dismantling the public distribution system, reducing budgets for social sector, promoting capital-intensive and 'high-tech' production, and increasing bank rates and insurance charges. The SAP policies aim at capital-, energy- and import-intensive growth with the help of devaluation, deregulation, deflation and denationalization. Mainstream economists call these processes "economic reforms".

Worse still, multinational corporations have long realized that the best way to reduce the wage bill and enhance profits is to move parts of the production process to poorer countries like Pakistan, India, Sri Lanka, Bangladesh, etc. The cheap labour of Asian women is regarded as the most lucrative way to enhance profits. Women in developing countries are a 'flexible' labour force. Their cheaper labour forms the basis for the induction of women into export industries such as electronics, garments, sports goods, food processing, toys, agro-industries, etc. Women are forced to work uncomplainingly at any allotted task, however dull, laborious, physically harmful or badly paid it may be. A large number of poor women looking for work within the narrow confines of a socially imposed, inequitable demand for labour have become ideal workers in the international division of labour.

The formal sector has control over capital and markets, and the 'informal' sector works as an additional. In Pakistan, more than $75 \%$ of women work in the decentralized sector, which has a high degree of labour redundancy. These women have almost no control over their work and no chance for upward mobility because of temporary and repetitive nature of the work.

The shift from an organized labour force to a flexible workforce has meant hiring women part-time, and the substitution of better-paid male labour by cheap female labour. The new economic policies provide State support to corporate houses that are closing down their big city units and using subsidiaries that employ women and girls on a piece-rate basis. Home-based work by women and girls gets legitimized in the context of increasing insecurity in the community due to a growth in crime, riots, displacement and relocation. Sub-contracting, home-based production, family labour system, all have become the norm. This is being called an increase in 'efficiency' and 'productivity'.

The SAP has forced working women into the unorganized sector and deprived them of their rights. The women fall outside protective labour laws such as the Maternity Benefits Act, Factories Act, Equal Remuneration Act, Labour Act, and Child Labour (Prohibition and Regulation) Act.

The government finds it difficult to dismiss permanent staff in public sector enterprises because they are organized, vocal and visible. A debate on the issue of part-time work for women creates a justification for segmentation of labourers on the grounds of gender. This deprives women of promotions and responsible assignments and discriminates 
against women by projecting them as "supplementary earners". Moreover, often the most strenuous part of work is commuting back and forth, and whether a person works parttime or full-time, the same amount of time and energy is spent on commuting. The argument in favour of part-time work for women does not question the existing genderbased division of labour in the family. It throws the burden of childcare and housework on the individual woman. Studies have shown that the burden of poverty falls more heavily on women than on men (Institutional impediments to human development in Pakistan)

The researchers in Pakistan have prepared studies on the consequences of SAPs and consistently protested, even if their voices are not loud enough. Despite having the highest gross national product per capita in South Asia after Sri Lanka, Pakistan's health indicators - such as infant mortality, maternal mortality and malnutrition -- are far below the average for low-income countries. Forty per cent of the disease burden in this country of 140 million people is from diarrhoea, acute respiratory infections, tuberculosis, and preventable childhood diseases. Between 8 and 33 per cent of mothers are anemic. Twenty-five per cent of Pakistani babies weigh less than 2,500 grams at birth. Ninety-one of every 1,000 children born die before their first birthday. One in two children between one and five years old is stunted, weighing abnormally little for his or her age - indicating long-term under-nutrition either from lack of food or from chronic diarrhoea. The root causes of all these problems are: poverty and inadequate health services for the poor - a situation that researchers feel is being aggravated by the SAP ((Institutional impediments to human development in Pakistan).

In 1998, Pakistan completed a comprehensive national health examination survey of its 148 million people, using internationally accepted research standards. The survey findings document a double burden for Pakistan. The nutritional deficiencies and infectious diseases of the past continue unabated while the chronic diseases associated with industrialization and urbanization have grown to epidemic proportions. One third of Pakistani children have stunted growth, while one third of Pakistani women older than 45 years have hypertension (Akhter, 2001).

There is a need to affirm the principles of national sovereignty, strong democracy, social justice, sustainable development, and gender equality. There is also a need to formulate clear guidelines to prevent unfair practices against labour, particularly women workforce and to ensure that minimum labour standards and working conditions required by law are likewise implemented where the overwhelming majority of the workers are women. There is also a need to turn around the policies that have burdened the entire nation with a huge social cost and institutionalized exploitation.

There is no doubt that the challenges confronting women have increased in this era of globalization. Women in Pakistan, like elsewhere in the developing world, face a 
growing sense of insecurity due to increasing competition being ushered in by globalization. Also, there is no guarantee of gaining access to the emerging opportunities unless steps are taken to increase their socio-economic empowerment. If Pakistan wants to prosper in this globalization era, it needs to ensure that the marginalized women across the country become more astute and efficient.

\section{References}

Akhter, Mohammad (Jan. 2001). "Health, Pakistan, and globalization". In American Journal of public health, vol. 91, No. 1.

Ali, Syed Mohammad (Oct. 12, 2004). "Is globalization good for women". In Daily Times, Lahore.

Arora, Guljit K., Gumber, Anil (2004). Globalization and health effects in SAARC region, evolving a framework of analysis In International Journal of Economic Development

Dass, Rakesh Peter (2002). Globalization: Effects in Asia and Beyond, Paper presented at the seminar on Globalization, Christian conference of Asia.

Institutional impediments to human development in Pakistan, Retrieved on March 20, 2009 http://www.wellesley.edu/Polisci/Candland/pakimped.pdf.

Jones, Andrew (2006). Dictionary of Globalization, Polity, Cambridge.

The Center for Dialogues: Islamic World - U.S. - The West, 2006, Retrieved on March 15, 2009 http://islamuswest.org/publications islam and the West/Who Speaks_For_Islam/Who-Speaks-For-Islam_05.html

Asma Manzoor is Lecturer at Centre of Excellence for Women's Studies, University of Karachi, Pakistan. She is enrolled in M.Phil/ Ph.D. Her areas of interest are: Women and Islam, Women and Law, Gender and Development, Women's History in South Asia and Women in Third World Countries.

Saba Imran Ali is Lecturer at Centre of Excellence for Women's Studies, University of Karachi, Pakistan. She is enrolled in M.Phil/ Ph.D. Her areas of interest are: Women and Psychology, Women's Movement, and Women's History in South Asia. 